\title{
Comparative study of plan for promoting physical activity for health between the territories of Strasbourg, Nice and Brest (France)
}

\author{
Bernard Massiera ${ }^{*}$, Valérie Morales-Gonzales ${ }^{2}$, Olivia Vitetta ${ }^{3}$ and Antoine Noel-Racine ${ }^{4}$ \\ ${ }^{1}$ Associate Professor, Lamhess, France \\ ${ }^{2}$ Assistant professor, ERCAE, France \\ ${ }^{3}$ Schoolteacher, UFR STAPS, France \\ ${ }^{4} \mathrm{PhD}$ Student, Lamhess, France
}

Submission: November 10, 2018; Published: November 26, 2018

*Corresponding author: Bernard Massiera, Associate professor, Lamhess, France

Abstract

The economic, health and societal consequences of inactive lifestyles encourage local governments to develop health promotion programs through physical activity PA for Health, WHO. The aim of this article is to better understand the mechanisms that have emerged in three territories (Strasbourg, Nice, Brest) and to bring them closer to the socio-ecological model of health promotion Booth [1]. Public and private funding, combined with a platform of centralized and cooperative organization for information and user orientation, and supplemented by the mobilization of insurance, health and sports actors, seem to be the first components of an ecological model of health promotion through physical activity in the French context.

Keywords: Comparative study, Socio-ecological model, Health promotion, France, Sport.

\section{Introduction}

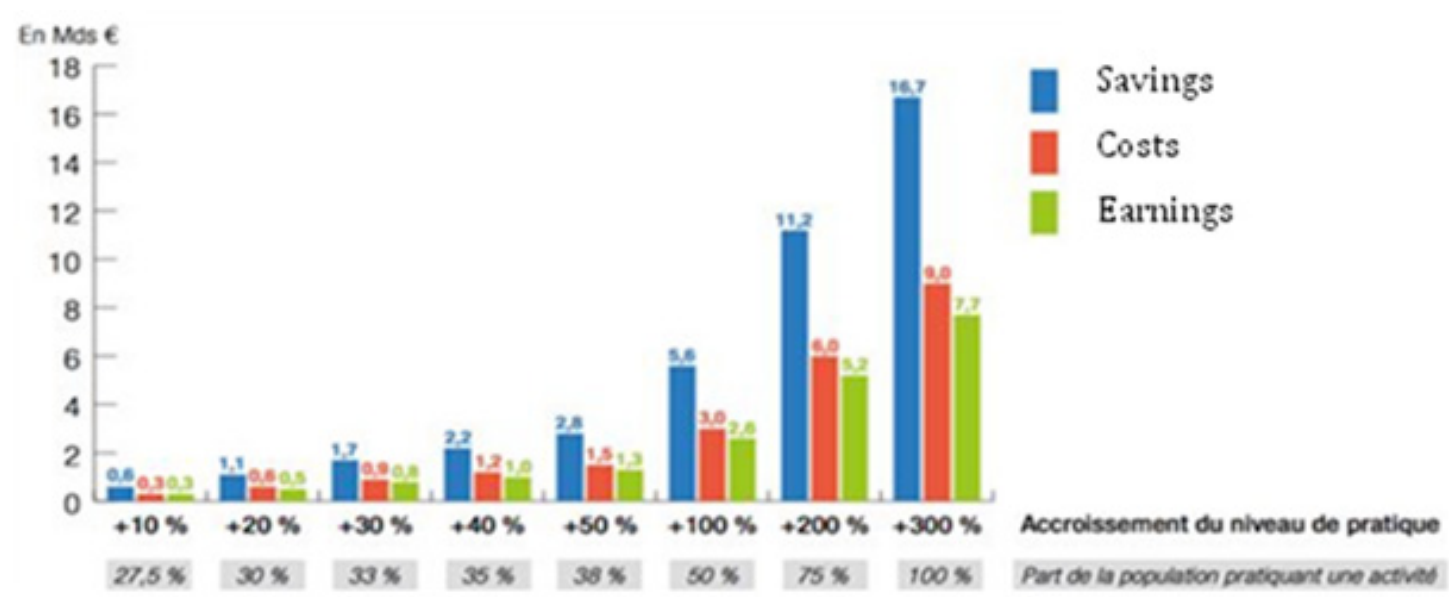

Figure 1: Gains achève by sports practice in France.

Note: This graph of the "Sport Eco" note is taken from the extrapolation of the Austrian study to France. It shows that a low growth in the level of practice generates savings Ministry of Sports [6].

Physical inactivity is responsible for one million deaths per year in the European Union Ministry of Health [2]. According to the 2017 Eurobarometer, 62\% of European citizens are "rarely" engaged in physical activity and $46 \%$ of them "never". This physical inactivity is a deleterious factor for health, resulting in increased health costs. Health expenditure in France represents 200 billion euros per year-i.e.-3, 000 euros per year and per person Ministry of Health [2]. The estimated share of physical inactivity represents 9.5 billion euros Center of Economics and Business Research. One of solutions to this financial waste seems to be the prevention of 
health through physical activity (Figure 1). Indeed, the annual savings made by an active person (30 minutes of walking per day) is estimated at 250 euros per person National Council of Physical and Sports Activities. The potential gains of prevention through physical activity is estimated between 1 and 10 billion euros per year Ministry of Budget. Since 2012, there has been a "reversal of the dynamics of sports spending" Ministry of the City, Youth and Sports. It is a transformation of the funding logic for sport that evolves due to the perception of physical activity as a drug Thévenon [3]. In addition, this desire is consistent with the trend to replace hospital care by drug treatments Elbaum [4].

\section{Objective and Problem}

Public action is moving in this direction and seeks to facilitate the development of physical activity for health in the territory with the problem of finding effective implementation mechanisms. The objective of our comparative case study is to find convergences between the different sport-health devices that emerged in three regions of France. Our work refers to the sociological theories of action logic Crozier and Friedberg [5] and mobilizes the ecological model of health Booth [1] but focuses on intermediate dimensions and on societal variables and individual factors (Figure 2). Indeed, the proliferation of health-oriented physical activity programs is developing in France and this action of health promotion at the national level involves exploring individual and collaborative parameters. The use of the ecological concept makes it possible to involve all the physical activity for health agents intervening at the heart of the device surrounding the user. Our problem is to identify, within the three territories, the invariants that stabilize the intermediate level (micro-environment \& interpersonal factors).

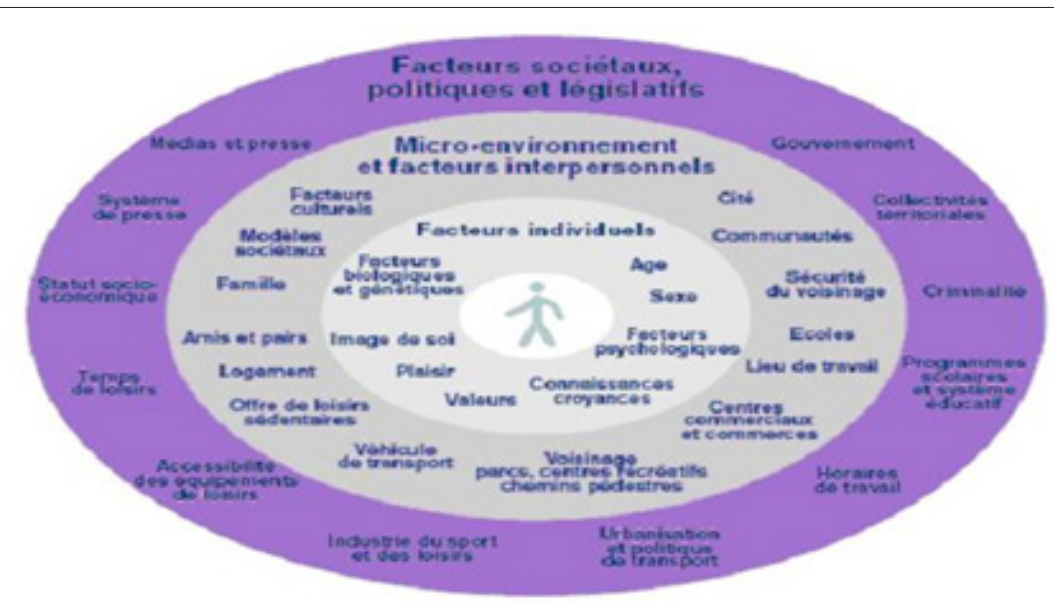

Figure 2: Socio-ecological model of health promotion

Source : Booth [1].

\section{Methodology}

To make an application of the socio-ecological approach (Canada) transferable to France, we proceeded by an inductive approach on the three sites (Table 1). Our work is realized by

Table 1: Investigation protocol of sport health devices. participating in the implementation of health sporting devices and investigating by observations, questionnaires and interviews conducted in Strasbourg (Greater-East Region) from 2008 to 2015, then in Nice (Provence-Alpes-Côte d'Azur Region) from 2015 to 2017 and finally in Brest (Brittany) from 2017 to 2018.

\begin{tabular}{|c|c|c|c|c|}
\hline $\begin{array}{c}\text { Methodology } \\
\text { Field }\end{array}$ & Observation & Interview & Questionnaire & Position \\
\hline Strasbourg (Alsace) & Métropole Strasbourg & Individual (16) & 1,247 people & Participation \\
\hline Nice (Côte d'Azur) & Association A2S & Individual \& collective (15) & $/$ & Participation \\
\hline Brest (Bretagne) & Prestataire APAS & Focus group (2x 5) & 100 people & Participation \\
\hline
\end{tabular}

\section{Results}

\section{Roles of Territorial Members in Sport-Health Develop- ment}

The results of our observations reveal five key dimensions in the development of physical activity for health programs (Table 2). The first dimension we observed differentiates the devices through the action of political actors. It is described as "decisive", "accompaniment" or "peripheral" depending on the political actors' participation in each territory. The second dimension identifies which health actors are involved in the dynamics of physical activity for health implementation: "medical practice", "hospital service" or "professional in physical activities". The third dimension concerns the commitment of the private agents in the three devices: they are "possible", "driving" (driving force) or "voluntary". In Strasbourg, the leader of the program is a deputy mayor, in Nice a team of doctors, and in Brest it is a personal initiative. Finally, the last dimension concerns the sports agents 
involved in the development of devices. These are the members of the sports department for Strasbourg, high-level athletes in Nice

Table 2: Action modeling of physical activity for health territorial agents. and professionals from the physical activity for health sector in Brest.

\begin{tabular}{|c|c|c|c|c|c|}
\hline Territories & Political action & Health action & Private action & Private action & Sports agents \\
\hline Strasbourg & Decisive & Medical practice & Possible & Deputy Mayor & City sport department \\
\hline Nice & Accompaniment & Hospital service & Driving & Medical team & High-level athletes \\
\hline Brest & Peripheral & Professionals in physical activity & Voluntary & $\begin{array}{c}\text { Personal ini- } \\
\text { tiative }\end{array}$ & $\begin{array}{c}\text { Professionals in physical } \\
\text { activity }\end{array}$ \\
\hline
\end{tabular}

\section{Organizational Aspects of Sport-Health Local Develop-} ment

We can see that three organizational models emerge. The first, which is expressed in Alsace (Strasbourg), is based on municipal public action. The second, which is at work in Brest, on for-profit services. The third model present in Nice, is a mixed form with diverse agents (researchers, doctors, private agents, representatives of the public action) joined in an associative development of physical activity for health on the Côte d'Azur.

\section{Ecological Model Applied to Sport-Health Local Devel- opment}

The application of the ecological model of health promotion to the implementation of sport-health in the French regions which were studied, is essentially concerned by the microenvironment dimension. However, we complement this modeling essay with the individual and societal dimensions that seem to play a decisive role in the operational aspect of the territorial program of PA for health (Figure 3).

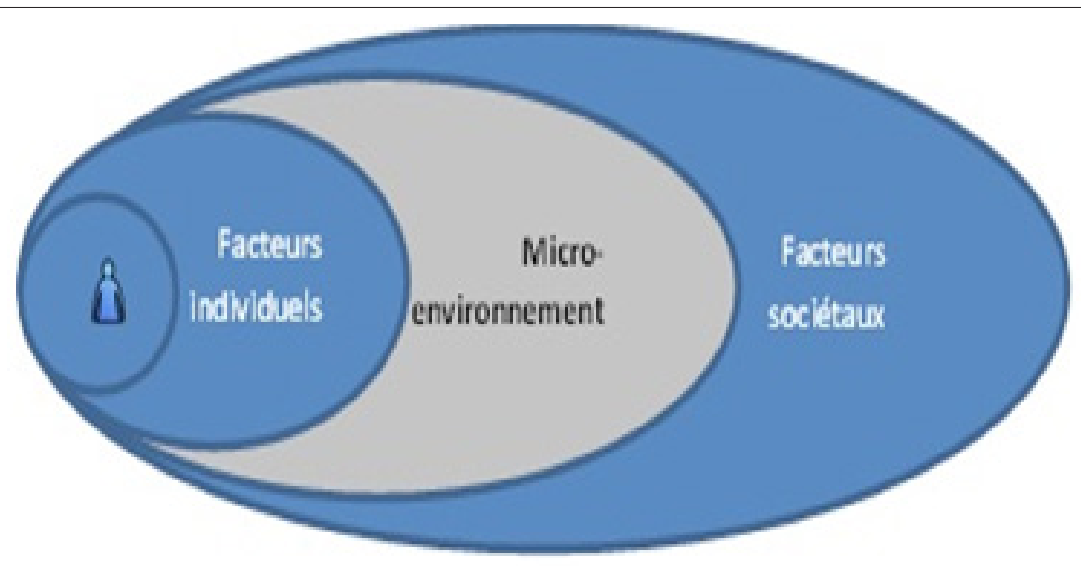

Figure 3: Modeling trial of the PA for health territorial development.

\section{Discussion}

This study highlights the importance of links between the populations concerned by the PA for health promotion program and their immediate environment (meso level). Indeed, the emergence of the devices present on the different territories is a consequence of the national injunctions (macro level). These devices adjust to the pathologies encountered and the patients' behaviors (micro level). It is the stability of the intermediate echelon (micro environment) that determines the global effectiveness of the program. This intermediate level is stable when it is materialized in the 4 dimensions of the " $4 \mathrm{P}$ " medicine model 4P Model: prediction, prevention, personalization and participation, National Institute of Health. The "prediction" aspect of the program is present in the genes and the users' way of life. "Prevention" is linked to the fact that this program intervenes before the diseases are declared. The "personalization" of the program ensures the effectiveness of the actions because food and physical exercises must be individualized. Finally, the "participation" of the population is essential because it allows everyone to become active in one's health Desplan [6]. These four dimensions, present in the intermediate level, invariably appear in the three territories and are decisive in the success of health promotion plans through physical activity [7-11].

\section{Conclusion}

What our comparative case study has highlighted is that the development of a prevention program of health through physical activity is based on two key actions. The first is the mobilization of health professionals on a fine medical approach, based on indicators (eat healthier, move better and control regularly) focused on patients Inserm. The second is the public awareness of physical activity benefits, identifying barriers to practice and consistency between the three program action levels (micro, meso and macro). It should be added that public funding may decrease and be replaced through financing by the users who want to "age well”. Finally, forms of mixed organization (involving private sector participation and public sector intervention) shape the PA for health sector, which should develop in polymorphic ways. 


\section{References}

1. Booth SL, Sallis JF, Ritenbaugh C, Hill JO, Birch LL (2001) Environmental and societal factors affect food choice and physical activity: rationale, influences, and leverage points. Nutr Rev 59(3): S21-39.

2. Ministère des Sports (2018) Sport éco, Bureau de l'économie du sport, Note d'analyse numéro 11.

3. Thévenon André (dir) (2013) Le sport est-il un médicament, éditions Sauramps médical, sous la Présidence du Docteur Alain Calmat, Conçu par un collectif d'auteurs ayant participés au colloque de Lille 9: 209.

4. Elbaum M (2010) L'évolution des dépenses de santé depuis vingt ans: quelques éléments d'analyse. Les Tribunes de la santé, hs 1(5): 15-29.

5. Crozier M, Friedberg E (1977) L'acteur et le système, Editions du Seuil, Paris, France.
6. Desplan JFB, Michel (2015) Consulté sur www.irdes.fr, Economie de la prévention en santé Pôle de documentation de l'Irdes-Marie-Odile Safon, citation p. 7.

7. Inserm (2008) Activité physique, Contextes et effets sur la santé, Expertise collective.

8. Rapport de la cour des comptes (2011) Communication à la commission des affaires sociales de l'Assemblée nationale.

9. Sallis JF, Cervero RB, Ascher W, Henderson KA, Kraft MK, et al. (2006) An ecological approach to creating active living communities. Annu Rev Public Health 27: 297-322.

10. Sallis JF, Owen N, Fisher E (2015) Ecological models of health behavior Health behavior: Theory, research, and practice 5: 43-64.

11. Cavill N, Kahlmeier S, Racioppi F (Eds.) (2006) Physical activity and health in Europe: evidence for action. World Health Organization.

\section{Your next submission with Juniper Publishers} will reach you the below assets

- Quality Editorial service

- Swift Peer Review

- Reprints availability

- E-prints Service

- Manuscript Podcast for convenient understanding

- Global attainment for your research

- Manuscript accessibility in different formats ( Pdf, E-pub, Full Text, Audio)

- Unceasing customer service

Track the below URL for one-step submission

https://juniperpublishers.com/online-submission.php 